\title{
Studier av hjertemuskelens funksjon med
} ultralyd

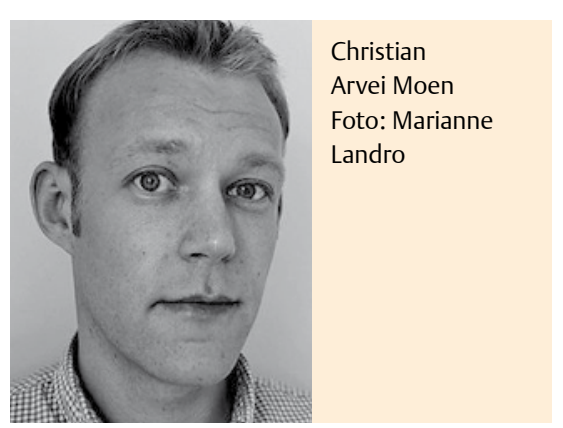

Christian Arvei Moen disputerte den 29. mai 2013 for ph.d.-graden ved Universitetet i Bergen med avhandlingen:

Myocardial deformation during ischemia and reperfusion. An experimental study of regional left ventricular function by Tissue Doppler Imaging and Speckle Tracking Echocardiography.
Angina pectoris skyldes forkalkning og stenose i koronararteriene. Ultralyd brukes rutinemessig for å blant annet diagnostisere redusert blodtilførsel til deler av hjertemuskelen. Nye metoder gjør det mulig å studere ved analyse av ultralydopptak deformasjon i områder av hjertet. Disse antas å tilføre diagnostikken mer nøyaktighet og objektivitet.

I en dyremodell ble ultralydmålingene utført direkte på hjertet.

Vevs-Doppler påviste lokale endringer etter hhv. reduksjon og gjenoppretting av blodstrømmen hhv. bedre eller like bra som mønstergjenkjenning.

Resultatene er lovende med tanke på fremtidig bruk av metodene i diagnostikk og vurdering av behandlingen hos pasienter med angina pectoris. 